\title{
PELAGIC SHRIMPS COLLECTED DURING THE TALUD I-VII CRUISES ABOARD THE R/V “EL PUMA” IN THE SE GULF OF CALIFORNIA, MEXICO
}

\author{
BY
}

\author{
MICHEL E. HENDRICKX ${ }^{1}$ )
}

Laboratorio de Invertebrados Bentónicos, Unidad Académica Mazatlán, Instituto de Ciencias del Mar y Limnología, Universidad Nacional Autónoma de México, P.O. Box 811, Mazatlán, Sinaloa 82000, Mexico

\begin{abstract}
A total of 15 species of pelagic shrimps were collected during the TALUD cruises I-VII (R/V "El Puma", UNAM) in 1990 and in 2000-2001 in the southeastern Gulf of California, including seven species of Dendrobranchiata (Hymenopenaeus doris, Sergia phorca, S. filicta, Parasergestes halia, Eusergestes similis, Gennadas incertus, and G. sordidus) and eight species of Caridea (Pasiphaea americana, P. emarginata, Hymenodora glacialis, Acanthephyra brevicarinata, A. cf. brevirostris, Plesionika trispinus and Maryprocessa pippinae). Most frequently collected species were G. sordidus (56\% of samples), S. phorca (40\%), P. emarginata (32\%), P. americana and $H$. doris (both 28\%). Most abundant species in the samples were G. sordidus, S. phorca, S. similis and P. trispinus. Sampling was performed between the surface to more than $2000 \mathrm{~m}$. This explains the presence of $P$. emarginata, a deep-water species rarely reported from the area and not found in much shallower samples taken by the R/V "El Puma" in 1981-1985.
\end{abstract}

Key words. - Pelagic shrimps, East Pacific, Benthesicymidae, Sergestidae, Solenoceridae, Pasiphaeidae, Acanthephyridae, Pandalidae, Processidae

\section{RÉSUMÉ}

Un total de 15 espèces de crevettes pélagiques ont été recueillies lors des campagnes TALUD I-VII (R/V "El Puma”, UNAM) en 1990 et en 2000-2001 dans le sud-est du golfe de Californie : sept espèces de Dendrobranchiata (Hymenopenaeus doris, Sergia phorca, S. filicta, Parasergestes halia, Eusergestes similis, Gennadas incertus et G. sordidus) et huit espèces de Caridea (Pasiphaea americana, P. emarginata, Hymenodora glacialis, Acanthephyra brevicarinata, A. cf. brevirostris, Plesionika trispinus et Maryprocessa pippinae). Les espèces les plus fréquemment recueillies furent G. sordidus (56\% des échantillons), S. phorca (40\%), P. emarginata (32\%), P. americana et $H$. doris ( $28 \%$ chacune). Les espèces les plus abondantes dans les échantillons furent G. sordidus, S. phorca, $S$. similis et $P$. trispinus. Les échantillons ont été collectés entre la surface et jusqu'à plus de $2000 \mathrm{~m}$

1) e-mail: michel@ola.icmyl.unam.mx

C Koninklijke Brill NV, Leiden, 2013 
de profondeur, ce qui explique la présence de $P$. emarginata, une espèce d'eau profonde rarement signalée dans la zone et absente des échantillons beaucoup moins profonds obtenus par le R/V "El Puma" en 1981-1985.

Mots clés. - Crevettes pélagiques, Pacifique Est, Benthesicymidae, Sergestidae, Solenoceridae, Pasiphaeidae, Acanthephyridae, Pandalidae, Processidae

\section{INTRODUCTION}

Pelagic shrimps of the Mexican Pacific are relatively well known, in particular in the California Current area and in the Gulf of California. The pelagic fauna of SW Mexico, however, has been much less studied. There is a huge gap of records roughly between Banderas Bay and the southern Gulf of Tehuantepec (Hendrickx \& Estrada-Navarrete, 1989, 1996). Since the first checklist of pelagic shrimps from the East Pacific was made available (Hendrickx \& Estrada-Navarrete, 1989) only a few contributions have been published on the subject. Guzman \& Wicksten (1998, 2000) reported on new records of pelagic Pasiphaeidae and on Benthesicymidae from Chile. Wicksten (2002) presented an extensive report on midwater decapods in the NE Pacific, including data related to the presence of 43 species of shrimps in this region. Hendrickx (2008) briefly reported on the presence of Hymenopenaeus doris Faxon, 1893, off Mexico and redescribed the genital appendages of a mature male. Guzman (2008) provided new records and a synthesis for 79 species of pelagic shrimps reported off Chile.

According to Hendrickx \& Estrada-Navarrete (1996), the pelagic shrimp fauna of the Mexican Pacific is composed of 53 species (29 Dendrobranchiata and 24 Caridea), but an additional species, Psathyrocaris fragilis Wood-Mason, 1893, was reported by Hendrickx \& Wicksten (2011).

In 1989 a project aimed at collecting deep-water invertebrates and fishes off the Pacific coast of Mexico was initiated (TALUD I-III). Intensive sampling was resumed in 2000-2001 (TALUD IV-VII). During these exploratory cruises in the SE Gulf of California, Mexico, pelagic shrimps were collected with different gear. Only a small part of the material collected during the TALUD I-III cruises has been reported by Hendrickx \& Estrada-Navarrete (1996). Additional material identified from supplementary samples is reported here.

\section{MATERIAL AND METHODS}

The pelagic shrimps reported in this contribution were collected during the ascent of otter trawls or benthic sledges, and in Isaac-Kidd midwater trawl (IKMWT) samples operated in deep water off the coast of Sinaloa, in the SE Gulf of California, roughly between $21^{\circ} 37^{\prime} \mathrm{N}$ and $26^{\circ} 06^{\prime} \mathrm{N}$. Otter trawls (TALUD I), 
Agassiz sledge (TALUD II-III), and a locally build benthic sledge (TALUD IVVII) were used at depths between 460 and 2240 m (see Hendrickx, 2012 for details). During the TALUD III an Isaacs Kidd midwater trawl was used to a maximum depth of $770 \mathrm{~m}$ (table I). All TALUD cruises were organized by the Laboratorio de Invertebrados Bentónicos (LIB), ICML, UNAM. Specimens were kept in a $4 \%$ formaldehyde solution, washed and preserved in a $70 \%$ ethanol solution. Additional, yet unreported material was obtained from the CORTES 1 cruise organized by the LIB, the CICIMAR 8405 cruise organized by the Centro Interdisciplinario en Ciencias del Mar, Instituto Politécnico Nacional (IPN), La Paz, Baja California Sur, and from the GUAYTEC II cruise organized by the Instituto Tecnológico de Monterrey, Guaymas, Sonora, Mexico. These samples are

\section{TABLE I}

Position of sampling stations visited during the TALUD survey in the SE Gulf of California and gear used at each station. Depth values are total depth at station (bottom trawl) or maximum depth reached by pelagic gear/total depth at sampling station. OT, otter trawl; AS, Agassiz sledge; BS, benthic sledge; IK, Isaac-Kidd midwater trawl

\begin{tabular}{|c|c|c|c|c|c|}
\hline Cruise & Station & Latitude (N) & Longitude (W) & Gear & Depth (m) \\
\hline TALUD I & 1 & $22^{\circ} 54^{\prime} 0^{\prime \prime}$ & $106^{\circ} 30^{\prime} 0^{\prime \prime}$ & OT & 170 \\
\hline TALUD III & 6 & $23^{\circ} 17^{\prime} 54^{\prime \prime}$ & $107^{\circ} 30^{\prime} 18^{\prime \prime}$ & AS & 996-1148 \\
\hline TALUD III & $16 \mathrm{~A}$ & $24^{\circ} 52^{\prime} 0^{\prime \prime}$ & $108^{\circ} 35^{\prime} 6^{\prime \prime}$ & AS & $216-224$ \\
\hline TALUD III & $16 \mathrm{~B}$ & $24^{\circ} 47^{\prime} 0^{\prime \prime}$ & $108^{\circ} 38^{\prime} 30^{\prime \prime}$ & AS & $579-608$ \\
\hline TALUD III & 17 & $24^{\circ} 33^{\prime} 0^{\prime \prime}$ & $108^{\circ} 50^{\prime} 54^{\prime \prime}$ & IK & 770 \\
\hline TALUD III & 19 & $25^{\circ} 12^{\prime} 0^{\prime \prime}$ & $109^{\circ} 7^{\prime} 0^{\prime \prime}$ & IK & $410(920)$ \\
\hline TALUD III & $20 \mathrm{~A}$ & $25^{\circ} 12^{\prime} 36^{\prime \prime}$ & $109^{\circ} 6^{\prime} 3^{\prime \prime}$ & AS & 966 \\
\hline TALUD III & 25-A1 & $25^{\circ} 51^{\prime} 0^{\prime \prime}$ & $109^{\circ} 57^{\prime} 0^{\prime \prime}$ & AS & $1280-1360$ \\
\hline TALUD III & $25-\mathrm{A} 2$ & $25^{\circ} 50^{\prime} 54^{\prime \prime}$ & $109^{\circ} 56^{\prime} 54^{\prime \prime}$ & IK & 230 (ND) \\
\hline TALUD IV & 13 & $23^{\circ} 17^{\prime} 30^{\prime \prime}$ & $107^{\circ} 29^{\prime} 51^{\prime \prime}$ & BS & 860 \\
\hline TALUD IV & 35 & $25^{\circ} 53^{\prime} 59^{\prime \prime}$ & $110^{\circ} 11^{\prime} 17^{\prime \prime}$ & BS & $2000-2100$ \\
\hline TALUD V & 11 & $23^{\circ} 14^{\prime} 0^{\prime \prime}$ & $107^{\circ} 0^{\prime} 0^{\prime \prime}$ & BS & $850-870$ \\
\hline TALUD V & 25 & $24^{\circ} 51^{\prime} 46^{\prime \prime}$ & $108^{\circ} 57^{\prime} 59^{\prime \prime}$ & BS & $800-860$ \\
\hline TALUD VI & 15 & $23^{\circ} 14^{\prime} 42^{\prime \prime}$ & $107^{\circ} 30^{\prime}$ & BS & 2390 \\
\hline TALUD VI & 27 & $25^{\circ} 1^{\prime} 12^{\prime \prime}$ & $109^{\circ} 11^{\prime} 36^{\prime \prime}$ & BS & $1580-1600$ \\
\hline TALUD VI & 34 & $25^{\circ} 43^{\prime} 50^{\prime \prime}$ & $109^{\circ} 53^{\prime} 59^{\prime \prime}$ & BS & $1240-1270$ \\
\hline TALUD VII & 4 & $22^{\circ} 3^{\prime} 18^{\prime \prime}$ & $106^{\circ} 34^{\prime} 42^{\prime \prime}$ & BS & $1200-1230$ \\
\hline TALUD VII & 5 & $22^{\circ} 0^{\prime} 24^{\prime \prime}$ & $106^{\circ} 39^{\prime} 54^{\prime \prime}$ & BS & $1490-1520$ \\
\hline TALUD VII & 12 & $23^{\circ} 18^{\prime} 18^{\prime \prime}$ & $107^{\circ} 26^{\prime} 48^{\prime \prime}$ & BS & $1040-1120$ \\
\hline TALUD VII & $13 \mathrm{~B}$ & $23^{\circ} 30^{\prime} 18^{\prime \prime}$ & $107^{\circ} 44^{\prime} 0^{\prime \prime}$ & BS & $1400-1450$ \\
\hline TALUD VII & 18 & $24^{\circ} 14^{\prime} 30^{\prime \prime}$ & $108^{\circ} 16^{\prime} 24^{\prime \prime}$ & BS & $950-1010$ \\
\hline TALUD VII & 20 & $24^{\circ} 14^{\prime} 48^{\prime \prime}$ & $108^{\circ} 35^{\prime} 12^{\prime \prime}$ & BS & $1480-1520$ \\
\hline TALUD VII & 25 & $24^{\circ} 52^{\prime} 48^{\prime \prime}$ & $108^{\circ} 58^{\prime} 0^{\prime \prime}$ & BS & $780-850$ \\
\hline TALUD VII & 27 & $25^{\circ} 1^{\prime} 30^{\prime \prime}$ & $109^{\circ} 12^{\prime} 0^{\prime \prime}$ & BS & $1580-1600$ \\
\hline TALUD VII & $32 \mathrm{~B}$ & $26^{\circ} 3^{\prime} 0^{\prime \prime}$ & $109^{\circ} 55^{\prime} 24^{\prime \prime}$ & BS & $850-880$ \\
\hline TALUD VII & $33 \mathrm{~B}$ & $26^{\circ} 6^{\prime} 30^{\prime \prime}$ & $110^{\circ} 6^{\prime} 42^{\prime \prime}$ & BS & $1260-1300$ \\
\hline TALUD VII & $34 \mathrm{~B}$ & $26^{\circ} 5^{\prime} 30^{\prime \prime}$ & $110^{\circ} 10^{\prime} 30^{\prime \prime}$ & BS & $1500-1520$ \\
\hline
\end{tabular}


included in this contribution. Most but not all identified specimens were kept in the holdings of the Regional Collection of Marine Invertebrates, in Mazatlán, Mexico, and the catalogue number of which (EMU-) is indicated in the material examined section. Specimens without a catalogue number were examined, identified and discarded.

\section{TAXONOMIC ACCOUNT}

A total of 215 specimens of pelagic shrimps belonging to 13 species ( 7 Dendrobranchiata and 6 Caridea; table II) were collected during the TALUD I-VII cruises.

\section{DENDROBRANCHIATA Spence Bate, 1888 \\ Benthesicymidae Bouvier, 1908 \\ Gennadas incertus (Balss, 1927)}

Material examined._- TALUD III, R/V “El Puma”. St. 17, 1 male (CL, 8.8 mm) (EMU-8135).

Remarks.- This appears to be the first record for this species within the Gulf of California. Hendrickx \& Estrada-Navarrete (1986) reported this species from off Baja California, in the California Current. Along the west coast of America, it ranges north to Oregon and south to Chile where it is not frequent (Guzmán, 2008).

\section{TABLE II}

Number of specimens of the 15 species of pelagic shrimps collected during the TALUD I-VII cruises. The number of samples in which each species was found is also indicated

\begin{tabular}{lcc}
\hline Species & Samples & Specimens \\
\hline Acanthephyra brevicarinata Hanamura, 1984 & 1 & 1 \\
Acanthephyra cf. brevirostris Smith, 1885 & 1 & 1 \\
Pasiphaea americana Faxon, 1893 & 6 & 8 \\
Hymenopenaeus doris (Faxon, 1893) & 8 & 9 \\
Pasiphaea emarginata Rathbun, 1902 & 8 & 20 \\
Sergia filicta (Burkenroad, 1940) & 2 & 3 \\
Hymenodora glacialis (Buchholtz, 1874) & 1 & 1 \\
Parasergestes halia (Faxon, 1893) & 3 & 5 \\
Gennadas incertus (Balss, 1927) & 1 & 1 \\
Sergia phorca Faxon, 1893 & 8 & 1 \\
Maryprocessa pippinae (Wicksten \& Méndez, 1985) & 1 & 13 \\
Eusergestes similis (Hansen, 1903) & 2 & 77 \\
Gennadas sordidus Kemp, 1910 & 14 & 16 \\
Plesionika trispinus Squires \& Barragán, 1976 & 5 & \\
\hline
\end{tabular}


Gennadas sordidus Kemp, 1910

Material examined.- TALUD III, R/V "El Puma". St. 17, 2 juveniles (CL, 4.3-5.0 mm), 8 males (CL, 8.0-9.1 mm), and 21 females (CL, 6.0-10.2 mm) (EMU-8136); St. 19, 2 specimens (unsexed; not measured); St. 25 A-1, 3 juveniles (CL, 5.3-5.8 mm), 10 males (CL, 6.5-9.5 mm), and 9 females (CL, 8.0-11.8 mm) (EMU-8130); St. 25 A-2, 1 female (CL, $5.8 \mathrm{~mm}$ ).

TALUD IV, R/V “El Puma”. St. 13, 1 female (CL, $8.4 \mathrm{~mm})$.

TALUD VII, R/V “El Puma”. St. 4, 1 male (CL, 10.5 mm); St. 5, 1 female (CL, $6.5 \mathrm{~mm})$; St. 12, 2 females (CL, ca $5.5 \mathrm{~mm}$ ); St. 18, 2 females (CL, 8.2-8.4 mm) and 3 males (CL, 7.7-8.2 $\mathrm{mm}$ ); St. 25, 2 males (CL, 6.8-8.0 mm); St. 33B, 2 males (CL, 9.3-9.8 mm) and 4 females (CL, 6.5-9-3 mm) (EMU-6997); St. 34B, 2 males (CL, 8.0-8.7 mm).

Remarks. - This is the most common species of the genus in the Gulf of California, also frequent in the California Current. Previous to the series of samples obtained during the CORTES cruises (1982-1985) in the Gulf of California and other records (1981-1984) reported by Hendrickx \& Estrada-Navarrete (1996: 34), there were only three records for this species in this area (see Burkenroad, 1938). Most records between 1982 and 1985 were in $300 \mathrm{~m}$ of depth or less. Material reported herein resulted from midwater samples obtained between surface and up to $1400 \mathrm{~m}$ depth.

\section{Sergestidae Dana, 1852}

Sergia filicta (Burkenroad, 1940)

Material examined.- TALUD VII, R/V “El Puma”. St. 5, 1 male (CL, $15.2 \mathrm{~mm}$ ) (EMU-8174); St. 20, 2 females (CL, 16.5-19.8 mm) (EMU-8175).

Remarks. - The material collected in station 20 (two females) is reported here as $S$. filicta with some doubts. The male specimen of station 5, however, fits well with the description and illustrations of the petasma provided by Hanamura (1983). A rare species, known from only two localities in the East Pacific (Panama and Dowd Tablemount), this represents the first record of S. filicta within the Gulf of California.

\section{Sergia phorca Faxon, 1893}

Material examined.- TALUD III, R/V "El Puma". St. 6, 1 male (CL, $17.3 \mathrm{~mm})$ and 2 females (CL, 20.3-22.2 mm) (EMU-8132); St. 17, 1 male (CL, $26.0 \mathrm{~mm}$ ) and 1 female (CL, $19.7 \mathrm{~mm}$ ); St. 25 A-1, 3 males (CL, 15.6-19.1 mm) and 15 females (CL, 10.7-21.6 mm) (EMU-8124); St. 25 A2, 2 juveniles (CL, $10.4 \mathrm{~mm}$ ), 6 males (CL, 19.4-20.6 mm) and 10 females (CL, 14.2-24.9 mm) (EMU-8123).

TALUD VI, R/V "El Puma”. St. 34, 3 females (CL, 19.8-22.5 mm) (EMU-8133).

TALUD VII, R/V "El Puma”, St. 18, 1 male (CL, 13.2 mm); St. 34B, 1 male (CL, $17.5 \mathrm{~mm})$ (EMU-8134).

Additional material.- CICIMAR 8405, R/V “El Puma”, St. $17\left(24^{\circ} 25^{\prime} \mathrm{N}, 111^{\circ} 50^{\prime} 30^{\prime \prime} \mathrm{W}\right)$, 4/June/1984, mid-water trawl to $300 \mathrm{~m}$ depth (total depth: $1300 \mathrm{~m}$ ), 5 males (CL 14.8-26.5 mm) and 1 female (CL $13.7 \mathrm{~mm})$ (EMU-8121); St. $24\left(19^{\circ} \mathrm{N}, 2^{\circ} 01^{\prime} 11^{\prime \prime} \mathrm{W}\right), 3 / \mathrm{June} / 1984$, mid-water 
trawl to $250 \mathrm{~m}$ depth (total depth, $1700 \mathrm{~m}$ ), 1 male (LC $16.4 \mathrm{~mm}$ ) and 4 females (LC 16.6-21-3 mm) (EMU-8127).

Remarks.- Described from Panama and off the Galapagos, S. phorca had not been reported by Hendrickx \& Estrada-Navarrete (1996) for the Mexican Pacific, despite the many samples (most $<300 \mathrm{~m}$, or even $<200 \mathrm{~m}$ ) that were obtained and reviewed, and the reports by Faxon $(1893,1895)$ in the central Gulf of California. In the present study, however, it appeared as a relatively common (6 samples; 46 specimens) species in the area in bottom sampling gear operated between the surface and 996-1520 m depth (4 samples), and in two Isaac Kidds samples (0-770 and 0-230 m depth). Samples taken from off the west coast of Baja California (CICIMAR 8405 samples) contain specimens taken no deeper than $300 \mathrm{~m}$. Guzman (2008) reported great abundances of this species off the coast of Chile where specimens of up to $12 \mathrm{~cm}$ (total length) have been observed.

\section{Eusergestes similis (Hansen, 1903)}

Material examined.- TALUD III, R/V "El Puma". St. 25 A-1, 5 specimens (unsexed; CL, 9.2$10.4 \mathrm{~mm}$ ) (EMU-8125); St. 25 A-2, 8 specimens (unsexed, not measured) (EMU-8276).

Additional material.- CORTES 1, R/V “El Puma”, St. $23\left(28^{\circ} 44^{\prime} 36^{\prime \prime} \mathrm{N} 112^{\circ} 44^{\prime} \mathrm{W}\right), 13 / \mathrm{March} /$ 1985, mid-water trawl, 0-180 m depth (total depth $490 \mathrm{~m}$ ), 2 specimens (not measured). CICIMAR 8405, R/V “El Puma”, St. $24\left(19^{\circ} \mathrm{N} 25^{\circ} 01^{\prime} 11^{\prime \prime} \mathrm{W}\right), 3 / J u n e / 1984$, mid-water trawl, 0-250 m depth (total depth, $1700 \mathrm{~m}$ ), 4 females (not measured) (EMU-8138).

Remarks.- Recently assigned to Eusergestes Judkins \& Kensley, 2008 (see Judkins \& Kensley, 2008), E. similis has been reported from the Bering Sea to the Gulf of California. Material from the Gulf of California included herein and material reported by Hendrickx \& Estrada-Navarrete (1996: 61) present some variations that seem to indicate that the Gulf species might be distinct from the NW American species.

Parasergestes halia (Faxon, 1893)

Material examined.- TALUD I, R/V "El Puma". St. 1, 2 females (CL, 12.2-12.6 mm) (EMU8139).

TALUD III, R/V “El Puma”. St. 17, 3 females (CL, 10.7-12.5 mm) (EMU-8131); St. 25 A-1, 1 female (CL, $10.3 \mathrm{~mm})$.

Remarks.- Recently assigned to the genus Parasergestes Judkins \& Kensley, 2008 (see Judkins \& Kensley, 2008), P. halia had been previously recorded in the same area (see Hendrickx \& Estrada-Navarrete, 1996).

Solenoceridae Wood-Mason \& Alcock, 1891

Hymenopenaeus doris (Faxon, 1893)

Material examined.- TALUD VI, R/V "El Puma", St. 34, 1 male (CL, 18.9 mm) (EMU8171-A). 
TALUD VII, R/V "El Puma". St. 4, 2 females (CL, 11.5 mm) (EMU-8171-B); St. 5, 1 female (CL, 9.5 mm) (EMU-8171-C); St. 12, 1 female (CL, 11.5 mm) (EMU-8172); St. 13B, 1 female (CL, $16.2 \mathrm{~mm}$ ) (EMU-8181-A); St. 20, 1 male (not measured) (EMU-7518); St. 27, 1 female (CL, ca $11.0 \mathrm{~mm})$; St. 34B, 1 male (CL, $19.4 \mathrm{~mm})(\mathrm{EMU}-8180)$.

Remarks.- Hendrickx (2008) reported on two specimens (1 male, CL $22.8 \mathrm{~mm}$; 1 juvenile, CL, $9.9 \mathrm{~mm}$ ) collected during the TALUD VII cruise, R/V "El Puma", off the coast of Sinaloa in the SE Gulf of California, and included a redescription of the male petasma and the appendices masculina and interna of this species.

Including the material reported by Peréz-Farfante (1977: 283) and Hendrickx (2008), present records indicate that $H$. doris is rather frequent in the SE Gulf of California.

Caridea Dana, 1852

Pasiphaeidae Dana, 1852

Pasiphaea americana Faxon, 1893

Material examined.- TALUD III, R/V "El Puma”. St. 16A, 1 specimen (unsexed; CL, $22.1 \mathrm{~mm}$ CL) (EMU-8136); St. 16B, 1 specimen (unsexed; CL, 22.9 mm); St. 20A, 2 specimens (unsexed; CL, 19.7-20.5 mm) (EMU-8168); St. 25 A-1, 1 specimen (unsexed; CL, 16.9 mm); St. 25 A-2, 1 specimen (unsexed; CL, $17.8 \mathrm{~mm} \mathrm{CL}$ ).

TALUD VII, R/V "El Puma”. St. 18, 2 specimens (unsexed; CL, 16.2-21.5 mm).

Additional material.— GUAYTEC II, R/V "El Puma", St. 70B $\left(28^{\circ} 47^{\prime} \mathrm{N} 112^{\circ} 54^{\prime} \mathrm{W}\right), 10 / \mathrm{Au}-$ gust/1987, bottom dredge, 360-380 m, 2 specimens (unsexed; CL 11.3-15.9 mm) (EMU-8122).

Remarks. - This is without any doubt the most common species of Pasiphaeidae found off the coast of western Mexico (Hendrickx \& Estrada-Navarrete, 1996). Reported off the SW coast of Baja California and throughout the Gulf of California, this species is also known from Central America (Costa Rica) to northern Peru (Hendrickx \& Estrada-Navarrete, 1996) and to northern Chile (Guzmán, 2008), but without positive records in between.

\section{Pasiphaea emarginata Rathbun, 1902}

Material examined.— TALUD III, R/V "El Puma". St. 17, 1 specimen (unsexed; CL $18.6 \mathrm{~mm}$ ) (EMU-8119); St. 19, 2 specimens (unsexed; CL 16.0-27.6 mm); St. 20A, 1 specimen (unsexed; CL 22.9 mm) (EMU-8140); St. 25 A-2, 1 specimen (unsexed; CL $22.8 \mathrm{~mm}$ ) (EMU-8120).

TALUD V, R/V "El Puma”. St. 11, 3 specimens (unsexed; CL 24.2-36.8 mm) (EMU-8178); St. 25, 5 specimens (unsexed; CL 26.4-35.3 mm) and 1 ovigerous female (CL $34.7 \mathrm{~mm}$ ) (EMU-8166).

TALUD VII, R/V “El Puma”. St. 18, 1 specimen (unsexed; CL $17.1 \mathrm{~mm}$ ); St. 32B, 5 specimens (unsexed; CL 19.6-20.0 mm) (EMU-8167).

Remarks. - In their monograph on pelagic shrimps of the Mexican Pacific, Hendrickx \& Estrada-Navarrete (1996) did not report new material of this species. They concluded that maximum depth at which their samples were taken (mostly to $200 \mathrm{~m}$ depth) was probably not sufficient to capture $P$. emarginata, a species 
reported between 395 and $1000 \mathrm{~m}$. The samples of the TALUD cruises examined in this study were all obtained between 500 and ca $1400 \mathrm{~m}$, thus indirectly confirming this hypothesis.

Acanthephyridae Spence Bate, 1888

Acanthephyra brevicarinata Hanamura, 1984

Material examined._TALUD VI, R/V “El Puma”, St. 15, 1 male (CL 27.8 mm) (EMU-9620).

Remarks. - In their monograph on pelagic shrimps of the Mexican Pacific, Hendrickx \& Estrada-Navarrete (1996) reported Acanthephyra brevicarinata in only three localities (4 specimens), all from the TALUD III cruise in the SE Gulf of California. Further deep-water sampling in the same area (2000-2001), however, indicated that it is a common, although not very abundant, species inhabiting below the Oxygen Minimum Zone core (Hendrickx, 2003).

\section{Acanthephyra cf. brevirostris Smith, 1885}

Material examined.- TALUD IV, R/V "El Puma”. St. 35, 1 specimen (unsexed; CL 5.8 mm) (EMU-8177).

Remarks.- Reported twice from the East Pacific (off Ecuador and off Mexico) (Faxon, 1893; Hanamura, 1983), A. brevirostris is a deep-water species also occurring in the Atlantic and the Indian oceans. The specimen examined has a broken rostrum but feature the large dorsal tooth on the third abdominal somite and would represent the first record for the Gulf of California.

\section{Hymenodora glacialis (Buchholtz, 1874)}

Material examined.— TALUD VI, R/V “El Puma”. St. 27, 1 specimen (unsexed; CL $16.5 \mathrm{~mm}$ ) (EMU-8173).

Remarks.- Another deep-water species of Acanthephyridae reported from the Atlantic, Indian and Pacific oceans, $H$. glacialis has been captured off Ecuador, Panama, Chile, and in the central Gulf of California (see Hendrickx \& EstradaNavarrete, 1996; Guzmán, 2008). This second record from Mexico confirms its presence in the Gulf of California.

Pandalidae Haworth, 1893

Plesionika trispinus Squires \& Barragán, 1976

Material examined.- TALUD III, R/V "El Puma". St. 17, 3 specimens (unsexed; CL 6.8$8.7 \mathrm{~mm}$ ) (EMU-8202), St. 25 A-1, 4 specimens (unsexed; CL 7.2-7-8 mm) (EMU-8129); St. 25 A-2, 6 specimens (unsexed; CL 4.0-8.9 mm) (EMU-8169-A).

TALUD VI, R/V "El Puma”. St. 34, 1 juvenile (CL 4.4 mm) (EMU-8169-B).

TALUD VII, R/V “El Puma”. St. 32B, 2 specimens (unsexed; CL 10.3-13.8 mm) (EMU-8170). 
Remarks. - The material examined herein was collected in a non-closing benthic sledge and, as in other similar situations (see Hendrickx \& EstradaNavarrete, 1986), it is impossible to assess at which depth it was caught. There is no doubt that $P$. trispinus might occur in the pelagic environment (see Hendrickx \& Estrada-Navarrete, 1996: 135), but further studies using closing midwater trawls or nets are needed to define the depth range of this species and its vertical migration pattern.

Processidae Ortmann, 1890

\title{
Maryprocessa pippinae (Wicksten \& Méndez, 1985)
}

\begin{abstract}
Material examined.- TALUD III, R/V "El Puma”. St. 25 A-2, 1 specimen (unsexed; CL 7.3 mm) (EMU-8201).

Additional material.— GUAYTEC II, R/V “El Puma”. St. 70B $\left(28^{\circ} 47^{\prime} \mathrm{N} 112^{\circ} 54^{\prime} \mathrm{W}\right), 10 / \mathrm{Au}-$ gust/1987, bottom dredge, 360-380 m, 4 specimens (unsexed; CL 4.9-7.9 mm) (EMU-8128).

Remarks. - A pelagic species within the family Processidae, M. pippinae is endemic to the Gulf of California. Dozens of samples examined from the southern Gulf and in the Mexican section of the California Current did not yield a single specimen of this species. Present record slightly extends the southernmost distribution limit of this species to the south within the Gulf of California.
\end{abstract}

\section{DISCUSSION}

This contribution include newly reported material for seven species of Dendrobranchiata and eight species of Caridea, including the first specimens of Sergia phorca and Pasiphaea emarginata ever captured by a Mexican research vessel. The most frequently collected species were Gennadas sordidus (56\% of samples), S. phorca (40\%), P. emarginata (32\%), P. americana and Hymenopenaeus doris (both 28\%). The most abundant species (i.e., number of specimens) in the samples were G. sordidus, S. phorca, S. similis and P. trispinus, but relative abundance is difficult to estimate due to use of several types of sampling gears with different mouth apertures. During the most recent TALUD cruises (from 2000 on) the deeper sampling limit was significantly increased compared to previous cruises in the same region. Sampling was performed between the surface to a depth of more than $2000 \mathrm{~m}$, thus explaining the presence of some deep-water species not collected previously.

Although only one sample was obtained in this survey, the presence of $G$. incertus off the coast of Sinaloa is noteworthy as it represents the second species of the genus known for the Gulf of California, the other, widely spread species, being G. sordidus. This unique sample was obtained from an Isaac Kidds mid-water 
trawl operated in 0-770 m depth. Previous intensive sampling in the epipelagic realm and to $200 \mathrm{~m}$ depth in this area (see Hendrickx \& Estrada-Navarrete, 1996) failed to reveal its presence. On the other hand, the upper and lower boundaries of the Oxygen Minimum Zone (OMZ) in the SE Gulf of California occur in 100$150 \mathrm{~m}$ (with almost anoxic values at $200 \mathrm{~m}$ depth) and 750-800 m, respectively (Hendrickx \& Serrano, 2010; Serrano \& Hendrickx, 2011), and it would therefore appear that $G$. incertus is also able to tolerate critically low oxygen concentrations values, as does G. sordidus (Hanamura, 1983).

Sergia filicta is a rare species featuring a wide distribution range in the East Pacific (about $13^{\circ} 28 \mathrm{~N}$ to $7^{\circ} 16^{\prime} \mathrm{N}$ ) (Hendrickx \& Estrada-Navarrete, 1996). The material collected during this survey in a benthic sledge operating at 1490-1520 m depth is the first record within the Gulf of California. Depth of previous records for this species are imprecise: total depth, $3650 \mathrm{~m}$ at type locality (Burkenroad, 1940); surface to $1632 \mathrm{~m}$ (three samples) and between 734 and $845 \mathrm{~m}$ (one sample) off Mexico (Hanamura, 1983). Sergia phorca, the only species of the genus occurring in the Gulf of California (Hendrickx \& Estrada-Navarrete, 1996), also appears to be a rather frequent species in the SE Gulf of California where it had not been collected before.

Pasiphaea emarginata, a deep-water species rarely reported from the area and not found in much shallower samples taken by the R/V "El Puma" in 1981-1985, was collected in seven stations ( 20 specimens) and must therefore be considered as a relatively common species in the area.

\section{ACKNOWLEDGEMENTS}

The author thanks all crew members, students and scientists who took an active part in sampling activities during the TALUD cruises aboard the R/V " $\mathrm{El}$ Puma" off the Pacific coast of Mexico, and Mercedes Cordero Ruiz for editing the manuscript. Ship time was provided by the Instituto de Ciencias del Mar y Limnología (TALUD I-III) and by the Coordinación de la Investigación Científica, UNAM (TALUD IV-VII). Financial support of CONACyT (project 31805-N) during the TALUD IV-VII cruises is acknowledged.

\section{REFERENCES}

Burkenroad, M. D., 1938. The Templeton Crocker Expedition. XIII. Penaeidae from the region of Lower California and Clarion Island, with descriptions of four new species. Zoologica, 23(3): 55-91. 
FAXON, W., 1983. Reports on the dredging operations off the west coast of Central America to the Galapagos, to the west coast of Mexico, and the Gulf of California, in charge of Alexander Agassiz, carried on by the U.S. Fish Commission steamer "Albatross", during 1891, Lieut. Commander Z. L. Tanner, U.S.N. commanding. VI. Preliminary descriptions of new species of Crustacea. Bull. Mus. comp. Zool. Harvard Univ., 24(7): 149-220.

- -1985 . Reports on an exploration off the west coast of Mexico, Central and South America, and off the Galapagos Islands, in charge of Alexander Agassiz, carried on by the U.S. Fish Commission steamer "Albatross", during 1891, lieut. Commander Z. L. Tanner, U.S.N., commanding. XV. The stalk-eyed Crustacea. Mem. Mus. comp. Zool. Harvard Univ., 18: 1292.

GuZMÁn, G., 2008. Camarones pelágicos (Crustacea: Decapoda) en aguas del Pacífico sureste. Contrib. Estudio Crust. Pac. Este, ICML, UNAM, 5(1): 27-45.

GuZMÁn, G. \& M. K. WiCKSTEN, 1998. Nuevos registros de camarones de la familia Pasiphaeidae (Crustacea: Decapoda) en el norte de Chile ( $18^{\circ}$ a $22^{\circ}$ Lat Sur, $70^{\circ}$ a 72 Long W). Gayana Zool., 62(2): 203-210.

— — \& — - 2000. The subfamily Benthesicyminae Bouvier, 1908 (Decapoda, Dendrobranchiata) in northern Chile $\left(18^{\circ}\right.$ to $\left.22^{\circ} \mathrm{S}\right)$. Crustaceana, 73: $925-931$.

Hanamura, Y., 1983. Pelagic shrimps (Penaeidea and Caridea) from Baja California and its adjacent region with description of a new species. Bull. biogeog. Soc. Japan, 38(8): 51-85.

HENDRICKX, M. E., 2001. Occurrence of a continental slope decapod crustacean community along the edge of the minimum oxygen zone in the southeastern Gulf of California, Mexico. Belgian Journ. Zool., 131(Suppl. 2): 95-109.

- _, 2003. Size and abundance of deep water shrimps on the continental slope of the SE Gulf of California, Mexico. In: M. E. HendrickX (ed.), Contributions to the study of East Pacific crustaceans. [Contribuciones al Estudio de los Crustáceos del Pacífico Este], 2: 227-234. (Instituto de Ciencias del Mar y Limnología, UNAM, Mexico).

-, 2008. New records and notes on decapod crustaceans in the east Pacific. Crustaceana, 81: 999-1006.

— —, 2012. Operaciones oceanográficas en aguas profundas: los retos del pasado, del presente y del proyecto TALUD en el Pacífico mexicano (1989-2009). In: P. ZAMORANO, M. E. HENDRICKX \& M. CASO (eds.), Biodiversidad y comunidades del talud continental del Pacífico mexicano: 23-104. (Secretaría del Medio Ambiente y Recursos Naturales, SEMARNAT, Instituto Nacional de Ecología, INE, México), in press.

Hendrickx, M. E. \& F. D. Estrada-Navarrete, 1989. A checklist of the species of pelagic shrimps (Penaeoidea and Caridea) from the eastern Pacific with notes on their geographic and depth distribution. CalCofi Rep., 30: 104-121.

—— \& — - 1996. Los camarones Pelágicos (Crustacea: Dendrobranchiata y Caridea) del Pacífico mexicano: 1-157. (Comisión Nacional para el Conocimiento y Uso de la Biodiversidad e Inst. Cienc. Mar y Limnol., UNAM, Mexico).

HendrickX, M. E. \& D. SerRano, 2010. Impacto de la zona de mínimo de oxígeno sobre los corredores pesqueros en el Pacífico mexicano. Interciencia, 35(1): 12-18.

HENDRICKX, M. E. \& M. K. WiCKSTEN, 2011. New distribution ranges and records of caridean shrimps (Crustacea: Decapoda: Caridea) from the west coast of Mexico. Hidrobiologica, 21(1): 26-33.

JudKins, D. C. \& B. Kensley, 2008. New genera in the family Sergestidae (Crustacea: Decapoda: Penaeidae). Proc. Biol. Soc. Wash., 121(1): 72-84.

PÉreZ-Farfante, I., 1977. American solenocerid shrimps of the genera Hymenopenaeus, Haliporoides, Hadropenaeus new genus and Mesopenaeus new genus. Fish. Bull., 75: 262-346.

SERrano, D. \& M. E. HendrickX, 2011. Debajo de la zona de mínimo oxígeno. Invest. Cienc., 417: $13-15$. 
Wicksten, M. K., 2002. Midwater decapods of the Northeastern Pacific. In: M. E. HendRICKX (ed.), Contributions to the study of East Pacific crustaceans. [Contribuciones al Estudio de los Crustáceos del Pacífico Este], 1: 127-144. (Instituto de Ciencias del Mar y Limnología, UNAM, Mexico). 